\title{
Transition Blues: The Experience of Female
}

\section{Collegiate Student-Athletes}

\author{
Kelsie Saxe \\ Texas Christian University \\ Robin Hardin, Ph.D. \\ University of Tennessee \\ Elizabeth A. Taylor, Ph.D. \\ Temple University \\ Joshua R. Pate, Ph.D. \\ James Madison University
}

\begin{abstract}
The purpose of this study was to explore the experiences of female student-athletes throughout a collegiate career. In the study, the experience of transition emerged as a key finding. Data were collected from ten female student-athletes in their third or fourth year of eligibility at an NCAA Division I Football Bowl Subdivision (FBS) institution. Each student-athlete participated in an in-depth, semi-structured interview in order for the researcher to gain a deeper understanding of her transitioning experience. A constant comparative data analysis method was used. This required the researcher to interact with the data to find similarities and trends. Utilizing this analytic method, the researcher then took the data and determined the findings. The findings in this study provide a better understanding of transitional experiences with female student-athletes and will enable administrators, coaches, support staff, and other stakeholders to make more informed decisions to assist them into and out of collegiate athletics. The two primary themes that emerged from the interviews were student-athlete's own transition into and out of collegiate sport as well as the transition of their coaches and teammates. The findings from this study provide a foundation to increase awareness of the current issues female student-athletes face out of the realm of sport and to better assist them during the collegiate experience.
\end{abstract}

Keywords: transitioning, women, student-athletes, NCAA 
Student-athletes are highly invested in their sport in a collegiate atmosphere. Even their college choice is likely based on the opportunity to participate in sport. They also devote the majority of their time to activities related to their sport participation, i.e., practice, workouts, injury rehabilitation, and competition. The National Collegiate Athletic Association (NCAA) found that on average, football, basketball, and baseball players in Division I spend approximately 40 hours a week on athletic activities; no sport in any division had an average lower than 28 hours (New, 2015). This deep immersion leads many student-athletes to feel incompetent without their sport and they may no longer see themselves as having personal, autonomous traits; instead, they see only their social traits associated with being an athlete as important (Cote, 1999; Cote, Baker, \& Abernethy, 2003; Kleiber \& Kirshnit, 1991). Their plans and goals revolve purely around their sport and athletes with high athletic identities who transition out of collegiate sports can experience difficulties that cause negative physical and mental outcomes (Blinde \& Stratta, 1992; Lally, 2007; Pearson \& Petitpas, 1990).

Women's participation in the NCAA has nearly tripled in the past 30 years to approximately 208,000 student-athletes in 2014, and the number of women's teams has more than doubled to more than 10,000 during that same time frame (Irick, 2014). The number of women working in intercollegiate athletics has steadily been rising and approximately 14,000 women were employed within intercollegiate athletics in 2014, the highest number ever recorded (Acosta \& Carpenter, 2014). This is approximately $35 \%$ of all administrative positions and women hold approximately $25 \%$ of all head coaching positions (Bass, Hardin, \& Taylor, 2015; DeHass, 2007; Irick 2011). The number of women seeking to enter into the profession of intercollegiate athletics is rising steadily as well. Approximately 550 women were either graduate assistants or interns during the 1995-96 year and that number jumped to 2,248 for 2009-10, an increase of nearly $400 \%$. The NCAA reported 2,919 women in graduate assistant or intern roles in 2015 (Irick, 2011). Women comprise nearly $45 \%$ of all student-athletes competing in the NCAA so there is a need to examine this population (Irick, 2014).

Many people contribute to the experiences of collegiate student-athletes ranging from coaches, administrators, athletic trainers, to faculty, family, and teammates. It is important to understand the perspective of the student-athlete transition experience in order to effectively meet the needs of student-athletes. Research has explored specific experiences and specific populations within female student-athletes such as identity formation (Percy, 2008), depression (Jones, Butryn, Furst, \& Semerjian, 2010), eating disorders (McLester, Hardin, \& Hoppe, 2014), and race (Bruening, Armstrong, \& Pastore, 2005). However, there is a gap in the research regarding collegiate female student-athletes and their transitioning experience. Gaining an understanding of the unique experiences of collegiate female student-athletes will enable future female studentathletes to better prepare for the transition experience. Coaches, administrators, sports psychology consultants, athletic trainers, athletic support staff, and any other stakeholders may assist more appropriately by being more aware and more knowledgeable of these stages of female studentathletes. Thus, the purpose of this research was to gain an understanding of the transition experience of female student-athletes. 


\section{Purpose of the Study}

Specific aspects of the experiences of the collegiate female student-athlete have been explored, but this study will focus on the experience of transitioning in and out of sport. Burton, VanHeest, Railis, and Reis (2006) explored the experience of talent development among female Olympians in the United States. Jones et al. (2010) explored the experience of female-studentathletes suffering from depression. Post and Wrisberg (2012) explored the lived experience of imagery in female collegiate gymnasts. None of these studies have explored the experience of the female student-athlete in relationship to her collegiate career and the transitioning process.

It is critical to remember that each experience will be different when exploring this topic. Burton et al. (2006) wrote, "each athlete has a unique story to tell, and a unique set of circumstances to convey when reflecting back on individual journeys" (p. 124). The experiences of the student-athletes participating in the study were personal to them, yet many had thematic similarities, through which the researchers sought to derive meaning. This study builds on the existing literature regarding the experience of the collegiate female student-athlete and the meaning associated with such experiences.

\section{Literature Review}

\section{Transitioning}

Schlossberg's Transition Theory guided the conceptualization of this study. Transition is any event or non-event that results in changed relationships, roles, identity, or routines (Schlossberg, 1981). People will continually experience change as they move through different stages of life and these changes will impact the person experiencing them (Schlossberg, 1981). The transition will result in new relationships, new networks, new behaviors, and different selfidentities (Schlossberg, 1981). The meaning and experience of the transition is different for each person, as individual experience will factor into the transition process, but there will always be some sort of change. Graduation from college is an anticipated transition since it is the end of a competitive athletic career for student-athletes (Evans, Forney, \& Guido-DiBrito, 1998).

The idea of transitioning out of competitive athletics has been a well-documented topic of research. Transition can be caused by a variety of events that include retirement, injury, or deselection, when student-athletes and professional athletes experience challenges such as lack of post-sport planning, a sense of loss, a period of personal growth, and adaptation (Blinde \& Stratta, 1992; Crook \& Robertson, 1991; Greendorfer \& Blinde, 1985; Harrison \& Lawrence, 2003, 2004; Kerr \& Dacyshyn, 2000; Kleiber \& Brock, 1992; Lally, 2007; Lavallee, 2006; Stankovich, Meeker, \& Henderson, 2001; Werthner \& Orlick, 1986). Planning for a transition in sport makes studentathletes more aware of life after sport since it forces them to face the reality that their athletic career has an end date (Harrison \& Lawrence, 2003, 2004). These challenges of transition into retirement offer similar characteristics of the transitions student-athletes face when moving through stages of their athletic career (e.g., high school to college). Retiring athletes typically endure a transitional period of six months to a year when they adjust to life beyond their sport (Sinclair \& Orlick, 1993). Similarly, student-athletes transitioning from high school to college face a parallel timeline for adjustment. 


\section{Transitioning into Collegiate Sport}

Research on transitioning into collegiate sport has been categorized into three primary areas: (a) athletic, (b) social, and (c) academic. Much of a college's focus regarding the transitioning process occurs at the athletic level, but that is evolving since programs have emerged within the NCAA and athletic departments to assist in the social and academic transitions of student-athletes.

Giacobbi et al. (2004) examined the transition of freshman female student-athletes who competed in the sport of swimming. Specifically, they explored how these student-athletes coped with stress. Freshman student-athletes face stress and the challenges associated with meeting the athletic demands as well as academic and social demands (Petrie \& Stover, 1997). Giacobbi et al. (2004) studied five participants of a successful swimming program at a NCAA Division I Football Bowl Subdivision (FBS) institution using interviews and focus groups. The results showed five main stressors: (a) training intensity, (b) high-performance expectations, (c) interpersonal relationships, (d) being away from home, and (e) academics. The issue of academics is relevant to the current study's focus on transitioning because of the weight academics has on the studentathlete experience. The academic transition is defined by Giacobbi et al. (2004) as "making the transition to university academic demands and balancing school with athletics" (p. 8).

The transitioning of freshman student-athletes also occurs in the adaptation process of being a new member of a team (Galipeau \& Trudel, 2004). Collegiate coaches determine the team roster but it is the existing team members who determine if a student-athlete is a team member or just a name on the roster. This has to do with acceptance and becoming part of the team community (Galipeau \& Trudel, 2004). Galipeau and Trudel (2004) interviewed 13 female student-athletes concerning their experiences as newcomers to their team. The findings discussed five stages of becoming an accepted team member, which shows that transition from high school to college is not merely arriving on campus. A process occurs in the transition from the introduction to other team members to becoming a full team participant. This process deals with adapting to the team culture and forging relationships with veteran team members and coaches (Galipeau \& Trudel, 2004). The change in coaches from high school to college also brings a transitional challenge (Pate, Stokowski, \& Hardin, 2011). This may require the student-athlete to adapt to an unfamiliar system.

Freshman student-athletes in particular have high levels of stress caused by the demands of high athletic performance expectations in addition to the change in academic environment. Stress from the athletic side comes from the areas of loss of star status, change in coaches, and the idea of being expendable (Papanikolaou, Nikolaidis, Patsiaouras, \& Alexopoulos, 2003). Academic stress arises from being underprepared, diminished self-esteem because of poor academic performance, and lack of decision-making ability (Papanikolaou et al., 2003). This stress arises from student-athletes being underqualified academically in comparison to the general student population of the incoming freshman class in addition to not having decision-making power in class scheduling and academic major choice (Gurney, 2009; Scheinder, Ross, \& Fisher, 2010; Upton \& Novak, 2008).

\section{Transitioning out of Collegiate Sport}


Transitioning out of sport is closely related to athletic identity formation. Athletic identity occurs in three stages: sampling years, specialized years, and investment years (Bloom 1985; Cote, 1999). In the early stages of sport development and commitment, athletes are typically between the ages of 6-12 and sample a variety of sports, develop motor skills, and focus on the excitement and learning process of the sport (Cote, 1999). In the specialized years, typically ages 13-15, the athletes begin to decrease their involvement in other extracurricular activities and tend to focus on one or two sports (Cote 1999; Cote \& Hay, 2002). Finally, the investment years begin at age 16. In this stage, athletes pursue deliberate practice and competition. Erikson (1968) described the specialization and investment years as most susceptible to identity molding because athletes begin viewing sport as a more serious endeavor.

The aspirations of participating in collegiate athletics begin to form and become a reality during the investment years. These athletes make the transition from using sport as a tool for enjoyment to a tool for entering college or even as a career as a participant or coach. This level of elevated commitment and move from sports as pure enjoyment to sports as a serious pursuit is integral to the athletic identity formation because "an adolescent athlete is able to think of him or herself as one who persists and endures in the face of obstacles, perhaps one who is courageous and can embrace adversity with poise and composure" (Kleiber \& Kirshnit, 1991, p.195). These adolescent athletes transition from playing high school or travel sport to elite sport competition that takes place in college, especially at the Division I level. Due to this new rise in competition, it is evident how student-athletes can be consumed in this identification as an athlete or a member of a team during athletic identity formation and attachment during adolescence. This identification only grows stronger in the environment of collegiate athletics. All of the requirements, commitments, and associations developed by student-athletes can create a deeply rooted sense of athletic identity.

\section{Negative Transition out of Sport}

Research has shown that negative associations can occur with the loss of identity in any stage of development (Erikson, 1968). However, having a strong athletic identity and the process of leaving sport can have harmful effects physically, mentally, and emotionally. Collegiate sports can cause restraint on time outside of sport, and for many student-athletes, their sport is their entire focus. Student-athletes must understand how to balance both academics and athletics, which greatly limits their time for developing relationships outside of their sport (Anderson, 2012). These student-athletes have added pressures of maintaining academic requirements to be eligible for competition and scholarship, practices, physical development, travel, and restrictions from social development available to their peers (Hardin \& Pate, 2013). In one study, researchers found that many athletes only developed relationships with their teammates or other athletes that endured similar experiences because of their restrictive schedules, which greatly affected their identity development, and caused harm in the future (Shurts \& Shoffner, 2004).

There is potential for a large sense of loss and a void when student-athletes exhaust their eligibility and they can even become delusional because of this intense focus or tunnel vision on athletics when they are no longer able to participate (Pearson \& Petitpas, 1990). For a studentathlete, it is not just the time commitment, but also a commitment to something greater than the individual player. This commitment to team, sport, and community is vastly important and when 
this ceases to exist, the athlete loses a connection to something greater than the self. This sense of loss can often be accompanied by psychological pain such as feeling out of control, a sense of helplessness, mood swings, depression, anxiety, and in some extreme cases, thoughts of suicide (Lally, 2007). This loss can even cause physical harm such as loss of appetite, changes to menstrual cycles, weight fluctuation, and insomnia (Blinde \& Stratta, 1992). A loss of identity for some athletes when transitioning out of sport can leave the athlete with an inability to move into the next stage of their life.

\section{Positive Transition Out of Sport}

Not all transition out of sport is negative and many athletes maintain a positive transition, transfer their skills from sport to their career, and develop a life after sport. Positive transition has been aided by coping mechanisms used by student-athletes on the brink of transitioning out of sport. Many of these methods involved developing a hobby or leisure pursuit to fill the void of time, seeking employment in another facet of sport, or simply moving into another career outside of sport that provides challenge and skill (Boixados, Cruz, Torregrosa, \& Valiente, 2004). The International Olympic Committee has become an advocate in the area of athletic identity. The committee echoed Boixados et al. (2004), stating that student-athletes who learned to foster interest in other areas and fields, cultivated strong support systems from family and friends, and developed time and stress management skills as well as social skills outside of sport can transition into life after athletics with more ease (International Olympic Committee, n.d.).

Another method for a smooth transition is the implementation of transferable skills that translate to career maturity and life after sport for student athletes. Transferable skills are acquired through sport and can be applied to other areas of an athlete's life and to other non-sport careers. These transferable skills include self-motivation, time management, organization, leadership, flexibility, and performing under pressure (Bernes et al., 2009). Bernes et al. (2009) also advocated that student-athletes understand how one's skills may be valuable in other areas, learn how one's skills may be useful in contexts other than sport, and understand how feelings of anxiety may accompany transition. This can be done through a focus on professional networking, resume writing, job interviewing, and learning how to incorporate their collegiate community as a resource for a future job (Stankovich et al., 2001). Student-athletes are more likely to dismiss a crisis and obtain the confidence needed to move onto a career after collegiate athletics if they can overcome the anxiety associated with transition, develop a new identity, and develop appropriate social support systems (Bernes et al., 2009).

Student-athletes that are able to develop various other identities and become involved in activities outside of sport seem to have more ease transitioning out of sport and into the next stage of their lives. These student-athletes are not consumed with being an athlete and perceive college as more than an athletic experience. Furthermore, they take the time to develop mentally, physically, and professionally for the next step of their lives.

\section{Methods}


Interviews were utilized in this study because they aid in finding the meaning of fundamental themes in the subject's life (Kvale, 1996). The participant's experiences were the focus of this study and the respondents acted as informants during the interview process by providing their unique perspectives on the topic (Yin, 1994). Interviews allow for a personal interaction between the researcher and participant and permits further probing and clarification with follow up questions.

Semi-structured interviews were conducted with a sample of 10 female Division I studentathletes at a NCAA Division I FBS university located in the Southeastern United States. The inclusion criteria were collegiate female student-athletes in their third and fourth-year of eligibility while competing in a NCAA Division I FBS institution. Female student-athletes from a variety of sports were sought. None of the participants transferred from another four-year institution. The researcher sought participants by finding female student-athletes who fit the criteria based on the information provided on the institution's athletic website. The researcher then contacted the coaches, directors of operations, graduate assistants, staff, administrators, and student-athletes of those particular teams to inquire about participation. This purposive or key informant sampling technique was utilized in order to find participants who met the criteria for participation (Creswell, 1994; Gratton \& Jones, 2004; Veal \& Darcy, 2014). The participants' experience as a female student-athlete made them acceptable subjects (Andrew, Pedersen, \& McEvoy, 2011).

The participants ranged in age from 20 to 22 . The university sponsored nine sports for women (basketball, golf, rowing, soccer, softball, swimming and diving, tennis, track and field, and volleyball) and there was one participant from each sport with two representatives from swimming and diving. Each participant chose a pseudonym to protect her confidentiality (see Table 1).

Semi-structured interviews were used to allow participants to fully explain their experiences and the open ended format of the interview questions allowed participants to put into words their perceptions, emotions, and feelings in an elaborate manner. The open-ended interview questions allowed the participants to interpret and guide the discussion based on what seemed most critical to discuss. A consistent concept that continually emerged was that of transitioning. The researcher sought to probe the discussion in a neutral manner to ensure that the participant was not being guided to particular answers. Transitioning emerged throughout the analysis and it became a central focus of the study. 
Table 1

Participant Demographics

\begin{tabular}{lllll}
\hline Participant & Sport & Eligibility & $\begin{array}{l}\text { Head Coach } \\
\text { Gender }\end{array}$ & $\begin{array}{l}\text { Coach } \\
\text { Change }\end{array}$ \\
\hline Emily & Tennis & 4th & Male/Female & No \\
Emma & Volleyball & 4 th & Male & Yes \\
Kylie & Soccer & 3rd & Male & Yes \\
Shawn & Swimming & 4 th & Male & Yes \\
Rachel & Swimming & 4 th & Male & Yes \\
Monica & Basketball & 4 th & Female & Yes \\
Liz & Softball & 4 th & Male/Female & No \\
Alex & Golf & 4 th & Female & Yes \\
Lacey & Track and Field & 4 th, 3rd & Male & Yes \\
Anna & Rowing & 4 th & Female & Yes \\
\hline
\end{tabular}

The follow-up and probing questions were based on the participants' responses to foundational questions in the interview (Merriam, 2009).

Two bracketing interviews were conducted to eliminate any biases before engaging with participants (Beck, 1994). In the first bracketing interview, the researcher conducted a mock interview as the researcher to practice and ensure neutral probing. The second bracketing interview was a mock interview with the researcher as the participant to ensure awareness of the researcher's biases before entering into interviews and analysis where the researcher has the power to influence data. Institutional Review Board approval was obtained and participants signed an informed consent form prior to the interview. All interviews were audio-recorded and transcribed verbatim by the researcher. The transcripts were then sent back to each participant for member checking (Morse, Barrett, Mayan, Olson \& Spiers, 2002). Anna was the only member to make changes to her transcript. She made changes via email that clarified some of her comments but did not reduce content. Member-checking allows the participants to review their interview transcript to ensure their responses were accurately transcribed (Andrew et al., 2011). Member-checking is one step in the data validation process (Gratton \& Jones, 2004). Each interview lasted approximately one hour and occurred in a quiet, safe, public location, e.g., conference room, office, and team room. 
Researchers should strive to achieve data saturation within qualitative studies, which occurs when new categories or themes stop emerging from the data according to Corbin and Strauss (2008). Corbin and Strauss (2008) provide the following guidance for qualitative researchers:

If a researcher determines that a category offers considerable depth and breadth of understanding about a phenomenon, and relationships to other categories have been made clear, then he or she can say sufficient sampling has occurred, at least for the purpose of the study. (p. 149)

Researchers deemed saturation had occurred after 10 interviews had been completed. Small sample sizes have been used by other sport researchers. Sutherland et al. (2014) had six participants in their study on female athletes and self-compassion and emotional pain. Additionally, Owton, Bond, and Tod (2013) had five respondents in their study exploring the expectations of novice sport psychology consultants.

A constant comparative data analysis method was used. During constant comparative data analysis, one segment of data is compared to another in order to find similarities and differences (Merriam, 2009). Data are grouped together based on a similar dimension; these groups become the themes of the study. The overall goal of this type of data analysis is to find patterns (Merriam, 2009). "Meaningful and manageable themes" were formed through grouping quotes of related experiences, challenges or ideas (Patton, 1987, p. 150). Exact wording was used as often as possible in order to retain and reflect the meaning of quotes portrayed by the participants during the interviews. During constant comparative analysis, the first step is to perform open coding. Open coding consists of the researcher coding the data for major categories of information (Creswell, 2013). From there, axial coding begins and researchers begin to relate categories to their subcategories (Mills, Durepos, \& Wiebe, 2010). The objective of axial coding is to identify a central characteristic around differences in dimensions. Therefore, axial coding is a technique where researchers reassemble data in a way that calls attention to relationships between and within categories (Mills et al., 2010).

The primary investigator read each transcript thoroughly before any coding occurred. The second time through, each case was coded independently using descriptive coding and the codes were then clustered into themes. The primary investigator then read through each transcript a third time and coded again to ensure that themes were not missed in any participants' transcript. Descriptive coding was employed to help facilitate the interpretation of each transcript. Once themes emerged from one case, the researcher then began reading and coding another participant's transcript. After the researcher coded and elicited themes from each transcript, they were compared for opposing or supporting themes throughout the sample. The themes that emerged in the coding were indicative of the student-athlete experience but the idea of transitioning was dominant throughout the coding process. The turnover in assistant coaches, the reality of their athletic career ending, and the duty to help others in their journey as student-athletes were themes that were prevalent throughout the interviews and in the transcripts.

The data analysis style used by the researchers in this study is a widely used method for analyzing qualitative research (Patton, 1987). Creswell (2013) provided eight criteria that need to 
be met in order to ensure trustworthiness of the data. The criteria for this study was prolonged engagement, rich and thick description, and member checking. The authors were engaged in the data analysis as they read the interview transcripts multiple times. The results were presented with multiple quotes in an attempt to provide rich and thick descriptions. Member checking, as described earlier, was employed by sending transcripts to each participant for verification.

\section{Results}

The feelings and emotions in regard to transitioning in and out of college sport were evident in the results. The interview with each respondent began with the question: Can you tell me about your experience as a student-athlete at UNIVERSITY? The discussion that followed that initial question invariably included the notion of transitioning involving themselves, teammates or coaches. Three primary themes emerged: a) transition blues, b) revolving door, and c) passing it on.

\section{Transition Blues}

Transition blues refers to the emotions that accompanied the transitions in and out of the student-athlete experience. This primarily occurred upon entering the institution and again when transitioning out of sport and preparing to retire from elite level competition. Freshman year blues was the role shift as well as the desire to prove oneself as a contributing member of the team. The senior year blues included a preparation for a role and lifestyle shift outside the realm of sport.

\section{Freshman year blues.}

Freshman year blues represents the vivid memory and arduous aspects within freshman year. Freshman year encompassed struggle and was also a time where the participants learned from teammates, particularly seniors, and felt as though they needed to prove themselves.

Nine of the participants referenced struggles in relation to their freshman year. The reasons for the struggle varied but they were prominent. The participants referenced feelings of wanting to go home, transfer, quit their sport, and feeling as though they were no longer the "star" of the team. Emma said, "I really struggled in class that fall semester my freshman year. I kind of felt like no one was helping me. I felt like I was drowning and no one was reaching out because there was so many issues on our team that year." Liz struggled with freshman year as well. She said she called her mom several times throughout the year and wanted to transfer. Monica said she was extremely homesick her freshman year. Her coaches and teammates would call her when she went home on a holiday break inquiring if she was coming back. Rachel faced significant struggle throughout her transition to college. She came in mid-year and needed surgery upon arriving. Additionally, she never took a recruiting trip so this was her first time to the institution and meeting her teammates. Although she tried, she could not hold back the tears when describing her experience her freshman year. She acknowledged that she felt more comfortable as a senior though the pain of her freshman year was evident. Rachel said, "My family and friends at home were really my support system [be]cause [deep breath] I felt like I wanted to stop." In instances like these, the participants expressed vulnerability. Shawn faced a similar situation to Rachel as she also came in mid-year. She felt as though the team was done making friends when she arrived and her role was left 
undefined. Shawn said, "I thought it was going to be the best thing to transfer. That was my first semester here. I really, really struggled."

Not only did the participants face the desire to transfer and quit, they also mentioned the aspect of coming into a prominent program and obtaining a smaller role on the team than they held previously on high school or club teams. Emma said, "Obviously that's a hard transition coming from high school and being one of the best players in the gym to coming to a place where it's all the top players in the gym all together at once." Similarly, Liz said that she was frustrated because she did not recognize herself as a player anymore. Everyone was used to being the star, including herself.

Many of the participants opened up about their struggles during freshman year, which were similar in that they wanted to quit, transfer, and return home, yet they didn't. Many followed up their statements of struggle with times of triumph to prove they had overcome this struggle. Emily said, "It's definitely harder than that [simply doing sports and taking classes], but I definitely think I made the right choice. I've had a great time here." Similarly, when Shawn explained her struggles during her freshman year, she said that she and her family can laugh about it now. The reward was greater than the struggle. However, some participants, such as Rachel, still had emotional attachments to the hard times. This was evident in the tears during interviews and exposed the emotional impression of some participant's experiences.

Pummell, Hardwood, and Lavallee (2007) conducted a study regarding career transitions for adolescent athletes. This study examined a different age group, yet is still informative because it speaks to the effects of transition intertwined with athletics and academics. Pummell et al. (2007) wrote:

An athlete making the athletic transition from mastery to perfection may be concurrently making the psychological transition from adolescence to adulthood as well as the transition from secondary to higher education... In addition to this, at the social level, the primary interpersonal support network for an athlete at this stage may shift from peers, parents, and coach to a partner and a coach. (p. 429)

It is important to recognize that a student-athlete is not just transitioning from high school to college. She is transitioning to a new team, level of sport, academic rigor, coaching staff, lifestyle, and set of demands. Some may even be transitioning to a new country and culture. While the team can serve as a good support system, these transitions need to be recognized and individuals need to be nurtured.

\section{Senior year blues.}

Many participants addressed their personal experience of transitioning out of sport as well as the transition off of the team. Three participants addressed pursuing sport professionally, while the others projected how they will transition into life outside of sport. Anna talked about the sadness she will experience when sport disappears. All of a sudden it will come to an end and the team will inevitably move on without her. Emma was the only senior on the team and struggled to hear the team talk about the upcoming season. When discussing next year, Emma said: 
Well next year we're going to win (conference) championships and go to NCAA. We're going to go to the Final Four. I'm pretty sick of hearing that. So, that's been the hardest part I think, of being the only senior. Is hearing how great everything's going to be next year when I have no part in that.

Additionally, Emma discussed the complexities of moving on from life as a student-athlete and the uncertainties she has with that experience. Emma said:

I've always had a pretty much set group of friends to fall into. I was able to like fall back on and be comfortable with like oh well I'm going to have practice or whatever. I always felt comfortable. I knew what was going to happen. I know what next spring is going to be like. I know what next fall is going to be like. Because it's going to be the same as it was last year. And I don't have that so it's a little bit weird.

When discussing moving forward, Shawn said:

It's nerve wracking. It's kind of sad. I don't want to leave. I love competing for this university and I love competing for the team. It's become a part of me. But at the same time it excites me in a sense that I know that it prepared me well for the next chapter and I'm excited for competing in the next phase.

Additionally, Monica discussed the idea of moving into life after college and taking the next step. Monica said: "It's kind of bitter sweet feeling now [be]cause I'm ready to get involved in the real world but am also going to miss the atmosphere and the experience that I had here." The general sense about moving on was the sadness associated with leaving something that they have invested so much time, energy, and identity into as well as the uncertainty the future brings, especially for those not pursuing sport professionally.

A vast amount of research addresses the transition blues and identity woes as studentathletes exhaust their eligibility (Albion, 2007; Falls \&Wilson, 2013; Lally, 2007.) Falls and Wilson (2013) sought the transition experiences of Canadian female student-athletes who previously played soccer in the NCAA. Falls and Wilson (2013) found that many participants utilized their team as a support system while transitioning into their university and during their student-athlete experience. However, upon completion of their athletic eligibility, many struggled without this support network. Beamon (2012) conducted a study with 20 African American men following their transition out of Division I athletics. One hundred percent of the participants reported struggling as they transitioned out of sport. Beamon (2012) wrote, "Most described feeling depressed and reported feeling a loss liken to personal death, the loss of a body part, or the loss of a family member" (p. 204). With the combination of these studies and the current findings, athletic departments need to be aware and proactive in facilitating the transition out of collegiate athletics.

\section{Revolving Door}


Another aspect of the transition experience was the change in teammates and coaches during their collegiate athletic career. Not only did seniors leave each year while freshman joined, some teammates would quit, transfer, or be dismissed. Athletes were not the only people in transition; coaches came and left, sometimes more than once per year. To illustrate this, Anna said, "The team dynamics have been so different all the different years. It just depends on who's there." Seven of the participants had a coaching change throughout their experience. Many of the participants felt that the coaching change was positive. Shawn said, "When she quit we added four new coaches. And it's safe to say that I'm really happy with the four coaches we added." Monica also had a coaching change during her sophomore year. When discussing her coaching change, Monica said, "And I'm kind of glad that I've had the opportunity to experience both eras. Finish up the (coach name) era and then begin the (new coach's name) era." Kylie had a similar perspective as Monica. When discussing the differences in coaching styles between the head coach her freshman year and her current head coach, Kylie said, "I'm kind of blessed to have both perspectives." Emma's sport position coach ended up leaving during her experience. She felt as though they were really close and she was upset that her head coach tweeted about it before telling the team in person. Additionally, Alex said, "I'm on my fifth assistant coach right now in four years." Although many of the coaching changes were positive, the great amount of change had a definitive impact on the participant's experiences. Coaches seemed to carry a significant weight within their collegiate experience.

There was also a great amount of turnover among teammates. Many of the participants started with a group of incoming student-athletes and that group dwindled through their career. Kylie stated, "Freshman year there was 11 of us that came in and I am graduating with three from the original class." Similarly Emma said, "When I came in there was six of us in my class. There were six freshmen. And a few of them left because of our coach. Quite a few people, I've had 16 people leave in my four years here." Emma said that her coach would not allow her to be friends with people who left the team or were dismissed and that was difficult for her. Emma was the only one left from her original class of six freshmen. Emma said:

It's been different coming in and having all of these girls so committed and so excited about (school) and (sport) and everything when we were in high school and senior year or even freshman year here. [We] were so excited about our future and what we're going to do. Then just seeing that kind of dwindle out one-by-one and then being the last one here.

Liz was also the last senior left in her class. She said, "About half of the class usually leaves each year, and so we had five and I was the only one. The only senior."

\section{Passing It On}

The transition out of their collegiate career also had special meaning to the participants. Senior year was also mentioned as a distinctive time period within the student-athlete experience. Most participants did not reference their sophomore or junior year unless they were trying to place a particular experience. However, senior year seemed to be an experience in itself. This was the time that they passed everything on to their team. The preparation for senior year began as freshmen. This is when they began learning from coaches, teammates, and particularly the 
upperclassmen that led their teams. This inspired them to pass on what they had learned and set an example for their younger teammates. The participants acknowledged that their athletic experience was a learning curve that began during their first few weeks on campus and now that they are transitioning out, they feel obligated to pass on their experiences to their teammates.

Many of the participants referenced the senior class or a particular senior on the team when they were freshman. They were able to form a connection, absorb the wisdom of that senior, and learn from them. Seniors on the team impacted the participants' experiences. Emily had one of the most distinct relationships with a senior her freshman year. Emily said, "When I was a freshman, my senior had a huge, huge impact on me. And she definitely taught me a lot about the university, the sport, the commitment, all those kind of values." Emma said, "She was an All-American all four years pretty much. And I saw how highly respected she was both on the court and off the court and looked up to her tremendously. She was a huge inspiration." Monica also mentioned the influence that her seniors had on her during her freshman season. She talked about the encouragement she received from the seniors when she faced adversity as a freshman. Lacey emulated an influential senior by leading her own underclassmen similarly to the way her senior teammates led her. Lacey said, "And her senior year it was just a huge switch. If I wasn't very focused in practice, she let me know. Now the girl under me if she's not focusing at practice I can remember my teammate." The only classes mentioned throughout each participant's experiences were the senior class, or one senior in particular, and the class in which the participants entered the institution. This spoke to the impact those seniors had on the underclassman on the team, both positively and negatively, depending on how they were led and if they attempted to make a connection with the underclassmen.

The participants expressed the desire to have that same impact on their younger teammates by being a good role model. Alex said:

I learned so much about myself. I learned so much about how to become a successful student-athlete here. I think not only has it benefitted me, but I feel maybe I've been able to pass that information down to some of my teammates. Maybe if that helps this team in future years. Then maybe it was all worth it.

Monica said:

I think I've just gotten to the point where now I'm stable in myself and my abilities and what I can do on and off the court so being able to help and give back to my teammates you know means a lot to me.

Rachel said she found meaning in her experiences through helping her teammates when they were struggling like she did. She would reach out to them and provide encouragement and support when they faced a difficult time. Lacey said the transition was natural instead of purposeful. Lacey said, "It has kind of seemed like a natural transition. It wasn't like okay I'm a senior now I better work hard and show people how it's done and teach them what people taught me." Emma said, "I'm trying to teach them [freshman] a lot too about being accountable for themselves and being accountable for their school and their decisions off the court really impact what goes on for everybody on the court and it really impacts our entire team." Although many of the participants 
have taught, helped, and supported the underclassman in different ways, teaching was a critical part of their role on the team. As Alex said, if she can help them, maybe her experience, injury, and hurt was worth it to prevent future suffering.

A part of setting an example was leading. Many of the seniors accepted a leadership role on the team. And many felt as though this role came with responsibility and challenges. Leading was harder than they had initially thought. Rachel said, "Being a senior I know people are looking up to me so I make sure I am setting a good example because that's important as a senior." What the seniors do is generally what the others will follow. There is a leadership group on Kylie's team. Kylie was in the leadership group her junior year and her redshirt year. During her redshirt year she was also considered a captain. When discussing her leadership role when she was injured, Kylie said:

The freshmen on the team have never even seen me play [sport]. So then it's like, I'm in this captain's role where usually your captains are on the field playing. I've kind of had to be careful with how I lead, especially the freshmen.

Emma has also found herself in a leadership role as the only senior on the team. Emma said, "After my entire class left I was kind of forced to step up which is fine but that's not really my personality. So that's been a big transition for me as well." Emma continued to say:

So being able to have people look up to me at first was really intimidating and really kind of terrifying, but I think I've adjusted pretty well to it and I can like understand what they want and what our coaches want and all that kind of thing.

Liz struggled to lead because she perceived her leading philosophy to be different than her coaches. She said, "They [coaches] said that I wasn't leading enough. Which in my way I was leading perfectly fine. But they wanted me to yell at teammates and that's not who I am. I lead by example. I help coach." Lacey has also found herself in a leadership role on her team. Lacey said:

When you're an underclassman, it's your job to perform at your best, and kind of fly under the radar. Or that's how it seemed. That's the vibes that I got as an underclassman. Just do your thing you know cheer on your teammates, like that's your job. And now it's kind of like okay, now I feel like I need to step up and be like well okay guys maybe you don't need to be screaming down the hallway of the hotel. I feel like it's my job to step up and be the leader, I guess.

Many of the participants discussed their leadership role as an upperclassman and their focus on leading and teaching the rest of their teammates through this role.

Another aspect of setting an example was leaving a legacy. Many of the participants discussed the legacy of being a student-athlete. Emma said, "Trying to go forward and finish out and kind of give people a reason to remember me because I don't want to be just a forgotten player that was here." Additionally, Alex recognized that when she is done, she hopes to leave something behind. Alex said, 
When I'm done playing college [sport] when I'm done at [institution], the only thing left behind of me is going to be what did I teach the girls? Did I help the coaches learn at all? That's it. You're done besides that.

It was evident that the participants wanted their experience to mean something not just to them but also to those around them. They wanted to be remembered as an important part of the team now and after they finish because of those that they influenced and taught. They wanted to leave a legacy.

\section{Discussion}

This study sought to explore the experiences of the female collegiate student-athlete. Through this exploration, the transition experience emerged. These findings add to the existing literature on the transition experiences of the collegiate female student-athlete and reveal a different perspective. The findings from this study can be applied to many stakeholders within the student-athlete experience.

Collegiate female student-athletes can apply these findings to enhance their experience. As freshman, it is important to prepare for the feeling of homesickness, particularly for out-of-state and international student-athletes. Parents can begin to prepare their children for this feeling and work together to come up with a plan of action to combat this feeling before leaving home (Berman $\&$ Sperling, 1991). Senior student-athletes will experience blues in relation to their athletic career ending and identity dissolving. Many of the participants felt anxious and confused about what to do and who they were during their senior year. Student-athletes need to begin preparing for the closure of their career the summer before their senior year in order to decrease the feelings of incompetence that can be felt without their sport (Côté et al., 2007; Kleiber \& Kirshnit, 1991).

Many of the participants found meaning through passing it on. No matter the experiences, positive or negative, if the student-athletes felt as though they were able to learn from these experiences, help someone else learn from their experiences, or pass down their newfound knowledge to their teammates, their experience seemed worthwhile. Seniors need to reflect and seek out ways such as these to promote meaning in their experiences and begin to engage in different identities to ease the transition out of elite sport. The benefits of these types of informal mentorship relationships have been examined in great detail and have been found to establish deeper and more valuable mentoring relationships (Chao, Walz, \& Gardner, 1992; Ragins \& Cotton, 1999).

Administrators can use these findings to promote a holistic experience for female studentathletes. Throughout the interviews, there was minimal discussion of being a student within the student-athlete experience. This reveals the identity associated with being a student-athlete and that little value is allocated to the student aspect of the experience. Administrators need to express the value of the student aspect of a student-athlete experience because student-athletes often become over-identified as athletes and neglect their academics (Anderson, 2012). Does the athletic department care about the student-athlete's grades because they want their student-athletes eligible or do they care about their grades because they value the student-athletes' holistic development and well-being? Additionally, administrators need to recognize the holistic needs of the student- 
athlete. Athletic departments can hire and offer counselors as a means to nurture the student-athlete emotionally and spiritually (Boerner, 2011; Fuller, 2014; Leonard \& Schimmel, 2016). Individual meetings with a counselor can provide an opportunity for continual reflection, strategy implementation, and meaning making throughout her career. There is a stigma attached to mental health resources, particularly within athletics, and administrators will need to prepare to oppose these inherent stigmas. If the administrators value the importance of emotional and spiritual wellbeing and student-athletes are encouraged to engage with counselors, this may help dissolve the stigma and promote holistic development and increase performance.

Support staff can apply these findings to diversify their resources to meet the needs of the collegiate female student-athlete. Leadership contributed significantly to the upperclassmen experience. As Emma mentioned, she was not a natural leader, yet she was put into a leadership role that intimidated her. Many other student-athletes may experience similar feelings and anxieties in regard to leadership. Support staff needs to provide leadership workshops and training for the student-athletes. Leadership takes training and skill development that needs to be fostered in these student-athletes. This will provide more effective leaders within teams and also provide student-athletes with leadership skills and training to implement after their collegiate career. Support staffs also need to provide group workshops and individual meetings to ease the studentathlete's transition in and out of collegiate sport (Smith, Taylor, Siegele, \& Hardin, 2015). These workshops can be coordinated among various support staff, including counselors, to meet the needs and concerns of the student-athlete as she feels homesick or begins to detach from a major identity. These can be done in group and individual settings to create unity in the process while also addressing individual needs.

Coaches can apply these findings to enhance the performance and experiences among the student-athletes on their team. Many times, coaches conjure dynamic relationships with their student-athletes that have significant influence over the student-athlete experience (Smith \& Hardin, 2015). Additionally, seniors felt as though they poured their hearts and souls into the team, institution, coaches, and sport throughout their journey as a student-athlete. However, a disconnect existed between the coach and student-athlete during her senior year. Emma said she felt as though her coach was already focused on the next year's incoming class and season before the current season was even over. She seemed deeply hurt by this notion. This is something that coaches need to consider and acknowledge. Seniors want to be recognized for their contributions to the team and sport. Although coaches need to prepare for the future, they need to try to limit their discussion of the upcoming season and demonstrate appreciation to their student-athletes for their contributions.

\section{Limitations}

There are certain limitations within this study that need to be acknowledged. These studentathletes were all from the same institution and same division. There may be varying experiences between divisions and different institutions within divisions. These experiences cannot be generalized to every collegiate female student-athlete, but it does provide a glimpse into the lives of student-athletes apart from the aspect of competition. 
It is also important to recognize that although a bracketing interview was used to bracket out the researcher's biases, biases can never be completely extracted. The researcher strived to stay close to the text and data throughout analysis. However, each researcher may have a slightly different interpretation of the same text.

Many of the interviews contained sensitive topics. The researcher acknowledged that these were sensitive topics and kept this in mind while probing.

\section{Recommendations for Future Research}

This study elicited rich data regarding the lived experiences of the collegiate female student-athlete and future research can be conducted to enrich the understanding regarding this population. Future research can focus on the lived experience of the female student-athlete at different divisions as well as institutions within the FBS Division I level. Scholars can explore the lived experiences of collegiate male student-athletes from a holistic perspective to decipher if these experiences are unique to women. Research could also examine the experiences of female studentathletes in relation to the gender of their head coach or the specific assistant coach the studentathlete works with the most.

The methodology employed for the purpose of this study allowed participants to fully embrace their experiences and share based on their perceptions rather than the researcher's agenda. Moving forward, phenomenology should be employed to cultivate depth of understanding with student-athletes in order to give voice to their experiences.

\section{Conclusions}

The experiences and performance of the collegiate female student-athlete involve much more than physical demands. Collegiate female student-athletes need to be acknowledged holistically, with physical, intellectual, social, spiritual, and emotional needs (Boerner, 2011; Fuller, 2014; Leonard \& Schimmel, 2016). The participants wanted their voices heard. There are many exit interviews at the conclusion of seasons or after eligibility is completed. Collegiate administrators should take note of this wealth of data and develop action plans based on this feedback. As athletic department stakeholders, one must understand their experiences and begin to implement action to prevent degradation of holistic development. This study adds to the literature as it provides the perspective of female student-athletes who are just now nearing the transition phase of their elite competitive sport careers. Focusing specifically on women in collegiate athletics provides a unique perspective to the transition process. Research has been conducted on transition but not with this specific population - women who have continually competed at the same university and are in the beginning stages of the transition process. One of the key findings of this research is the notion of the revolving door of assistant coaches the participants experienced and the impact on their collegiate athletic experience. Stakeholders can move forward with this data and implement this into decision-making and daily interactions with female student-athletes. 


\section{References}

Acosta, R. V. \& Carpenter, L. J. (2014). Women in intercollegiate sport: A longitudinal, national study thirty-five-year update 1977-2014 (unpublished manuscript). Retrieved from http://acostacarpenter.org

Albion, M. J. (2007, September). Restoring the balance: Women's experiences of retiring from elite sport. In Refereed Proceedings of the 2007 International Women's Conference: Education, Employment and Everything... the Triple Layers of a Woman's Life (pp. 3539). USQ Women's Network Inc.

Anderson, A. (2012). Helping college student-athletes in and out of sport. In B. Brewer, \& J. Van Raalte (Eds.), Exploring sport and exercise psychology. (2nd ed). Washington, DC: American Psychological Association.

Andrew, D., Pedersen, P., \& McEvoy, C. (2011). Research Methods and Design in Sport Management: Champaign, IL: Human Kinetics.

Bass, J., Hardin, R., \& Taylor, E. (2015). The glass closet: Perceptions of homosexuality in collegiate sport. Journal of Applied Sport Management, 7(4), 1-36.

Beamon, K. (2012). "I'm a baller": Athletic identity foreclosure among African-American former student-athletes. Journal of African American Studies, 16(2), 195-208.

Beck, C. T. (1994). Phenomenology: Its use in nursing research. International Journal of Nursing Studies, 31(6), 499-510.

Berman, W. H., \& Sperling, M. B. (1991). Parental attachment and emotional distress in transition to college. Journal of Youth and Adolescence, 20(4), 427-440.

Bernes, K. B., McKnight, K. M., Gunn, T., Chorney, D., Orr, D. T., Bardick, A. D. (2009). Life after sport: Athletic career transition and transferable skills. Journal of Excellence, 13, 63-77.

Blinde, E. M., \& Stratta, T. M. (1992). The "sport career death" of college athletes: Involuntary and unanticipated sport exits. Journal of Sport Behavior, 15(1), 3.

Bloom, B. S. (1985). Developing talent in young people. NY: Ballantine Books.

Boerner, W. A. (2011). Transitional leadership: Perceptions of interim mid-level student affairs professionals. Dissertation Abstracts International Section A: Humanities and Social Sciences, VO171(11-A), 3938.

Boixados, M. Cruz, J., Torregrosa, M., \& Valiente, L. (2004). Relationships among motivational climate, satisfaction, perceived ability, and fair play attitudes in young soccer players. Journal of Applied Sport Psychology, 16, 301-317. 
Bruening, J. E., Armstrong, K. L., \& Pastore, D. L. (2005). Listening to the voices: The experiences of African American female student athletes. Research Quarterly For Exercise \& Sport, 76(1), 82-100.

Burton, L. J., VanHeest, J. L., Railis, S. F., \& Reis, S. M. (2006). Going for gold: Understanding talent development through the lived experiences of US female Olympians. Journal of Adult Development, 13, 124-136.

Chao, G. T., Walz, P. M., \& Gardner, P. D. (1992). Formal and informal mentorship: A comparison on mentoring functions and contrast with nonmentored counterparts. Personnel Psychology, 45, 619-636.

Corbin, J., \& Strauss, A. (2008). Basics of Qualitative Research: Techniques and Procedures for Developing Grounded Theory ( $3^{\text {rd }}$ ed.). Thousand Oaks, CA: Sage.

Côté, J. (1999). The influence of the family in the development of talent in sport. The sport psychologist, 13 (4), 395-417.

Côté, J., Baker, J., \& Abernethy, B. (2003). From play to practice: A developmental framework for the acquisition of expertise in team sport. In J. Starkes and K.A. Ericsson (Eds.), Expert performance in sports: Advances in research on sport expertise, (pp. 89-113). Champaign, IL: Human Kinetics.

Côté, J., \& Hay, J. (2002). Children's involvement in sport: A developmental perspective. In J.M. Silva \& D.E. Stevens (Eds.) Psychological foundations of sport (pp. 484-502). Boston, MA: Allyn \& Bacon.

Creswell, J. W. (1994). Research design: Qualitative \& quantitative approaches. Thousand Oaks, CA: SAGE Publications, Inc.

Creswell, J. W. (2013). Qualitative inquiry and research design: Choosing among give approaches. Washington, DC: Sage Publications.

Crook, J.M. \& Robertson, S.E. (1991). Transitions out of elite sport. International Journal of Sport Psychology, 22, 115-127.

DeHass, D. (2007). 2005-06 ethnicity and gender demographics of NCAA member institutions' athletics personnel. Indianapolis, IN: National Collegiate Athletic Association.

Erikson, E. H. (1968). Identity, youth, and crisis. New York, NY: W. W. Norton.

Evans, N., Forney, D. S., \& Guido-Dibrito, F. (1998). Student development in college: Theory, research, and practice. San Francisco, CA: Jossey-Bass.

Falls, D., \& Wilson, B. (2013). Reflexive modernity and the transition experiences of university athletes. International Review for the Sociology Of Sport, 48(5), 572-593. 
Fuller, R. D. (2014). Transition experiences out of intercollegiate athletics: A meta-synthesis. Qualitative Report, 19(46), 1-15.

Galipeau, J. \& Trudel, P. (2004). The experiences of newcomers on a varsity sport team. Applied Research in Coaching and Athletics Annual, 19, 166-188.

Giacobbi, P. R., Lynn, T. K., Wetherington, J. M., Jenkins, J., Bodendorf, M., \& Langley, B. (2004). Stress and coping during the transition to university for first-year female athletes. The Sport Psychologist, 18(1), 1-20.

Gratton, C., \& Jones, I. (2004). Research methods for sport studies. London: Routledge.

Greendorfer, S. L., \& Blinde, E. M. (1985). Retirement from intercollegiate sport: Theoretical and empirical considerations. Sociology of Sport Journal, 2, 101-110.

Gurney, G. S. (2009). Now we must reform athletics reform. The Chronicle of Higher Education. Retrieved from https://projects.ncsu.edu/project/n4a/thelockerroom/documents/Chronicle\%20C ommentary\%200ctober,\%202009.pdf

Hardin, R. \& Pate, J. R. (2013). Playbook vs. textbook: Examining academic transitioning of NCAA division I-FBS football student-athletes. Journal for the Study of Sports and Athletes in Education, 7(3), 229-244.

Harrison, C. K., \& Lawrence, S. M. (2003). African American student athletes' perceptions of career transition in sport: A qualitative and visual elicitation. Race, Ethnicity and Education, 6(4), 373-394.

Harrison, C. K. \& Lawrence, S. M. (2004). Female and male student athletes' perceptions of career transition in sport and higher education: A visual elicitation and qualitative assessment. Journal of Vocational Education and Training, 56(4), 485-506.

International Olympic Committee. (nd). Athletic Identity and Sport Transition ( $1^{\text {st }}$ ed.). Lausanne, Switzerland: IOC.

Irick, E. (2011). Race and gender demographics: NCAA member institutions' personnel report. Indianapolis, IN: National Collegiate Athletic Association.

Irick, E. (2014). Student-Athlete Participation: 1981-1982 - 2013-2014. Indianapolis, IN: National Collegiate Athletic Association.

Jones, A. L., Butryn, T. M., Furst, D. M., \& Semerjian, T., Z. (2010). A phenomenological examination of depression in female collegiate athletes. Athletic Insight. Retrieved from http://www.athleticinsight.com/Vol15Iss1/Feature.htm 
Kerr, G., \& Dacyshyn A. (2000). The retirement experiences of elite, female gymnasts. Journal of Applied Sport Psychology, 12(2), 115-133.

Kleiber, D. A., \& Brock S. C. (1992) The effect of career-ending injuries on the subsequent wellbeing of elite college athletes. Sociology of Sport Journal, 9, 70-75.

Kleiber, D., \& Kirshnit, C. (1991). Sport involvement and identity formation. In L. Diamont (Ed.), Mind, body maturity: Psychological approaches to sports, exercise, and fitness (p. 193-212). Charlotte, NC: Hemisphere Publishing Corporation.

Kvale, S. (1996). InterViews—An introduction to qualitative research interviewing. Thousand Oaks, CA: Sage.

Lally, P. (2007). Identity and athletic retirement: A prospective study. Psychology of Sport \& Exercise, 8(1), 85-99.

Lavallee, D. (2006). Career awareness, career planning, and career transition needs among sport coaches. Journal of Career Development, 33(1), 66-79.

Leonard, J. M., \& Schimmel, C. J. (2016). Theory of work adjustment and student-athletes' transition out of sport. Journal of Issues in Intercollegiate Athletics, 9, 62-85.

McLester, C. N., Hardin, R., \& Hoppe, S. (2014). Susceptibility to eating disorders among collegiate female student-athletes. Journal of Athletic Training, 49(3), 406-410.

Merriam, S. B. (2009). Qualitative research: A guide to design and implementation. San Francisco, CA: Jossey-Boss.

Mills, A. J., Durepos, G., \& Wiebe, E. (Eds.). (2010). Encyclopedia of case study research. Los Angeles, CA: Sage.

Morse, J. M., Barrett, M., Mayan, M., Olson, K., \& Spiers, J. (2002). Verification strategies for establishing reliability and validity in qualitative research. International Journal of Qualitative Methods, 1(2), 1-19.

New, J. (2015). What off-season? Inside Higher Ed. Retrieved from https://www.insidehighered.com/news/2015/05/08/college-athletes-say-theydevote-too-much-time-sports-year-round

Owton, H., Bond, K., \& Tod, D. (2013). "It's my dream to work with Olympic athletes": Neophyte sport psychologists' expectations and initial experiences regarding service delivery. Journal of Applied Sport Psychology, 26(3), 241-255. 
Papanikolaou, Z., Nikolaidis, D., Patsiaouras, A., \& Alexopoulos, P. (2003). The freshman experience: High stress-low grades. Athletic Insight: The Online Journal of Sport Psychology. Retrieved from http://www.athleticinsight.com/Vol5Iss4/Commentary.htm

Pate, J. R., Stokowski, S. E., \& Hardin, R. (2011). Third time's a charm: The case of Tennessee's four junior football players who endured three different head coaches in three seasons. Journal of Issues in Intercollegiate Athletics, 4, 354-369.

Patton, M. Q. (1987). How to use qualitative methods in evaluation. Newbury Park, CA: Sage Publications.

Pearson, R. E. \& Petitpas A. J. (1990). Transitions of athletes: Developmental and preventive perspectives. Journal of Counseling \& Development, 69(1), 7-10.

Percy, V. E. (2008). Understanding identity and psychosocial functioning through the lived experiences of African American collegiate athletes participating in revenue producing sports: A hermeneutic phenomenological approach. Available from PsycINFO. (621736351; 2008-99110-462). Retrieved from http://search.proquest.com/docview/621736351?accountid=14766

Petrie, T. A. \& Stover, S. (1997). Academic and non-academic predictors of female student athletes' academic performance. Journal of College Student Development, 38, 599-608.

Post, P. G. \& Wrisberg, C. A. (2012). A phenomenological investigation of gymnasts' lived experience of imagery. The Sport Psychologist, 26, 98-121.

Pummell, B., Harwood, C., \& Lavalle, D. (2007). Jumping to the next level: A qualitative examination of within-career transition in adolescent event rides. Psychology of Sport and Exercise, 9(4), 427-447.

Ragins, B. R., \& Cotton, J. L. (1999). Mentor functions and outcomes: A comparison of men and women in formal and informal mentoring relationships. Journal of Applied Psychology, 84(4), 529-550.

Schlossberg, N. K. (1981). A model for analyzing human adaptation to transition. The Counseling Psychologist, 9, 2-18.

Schneider, R. G., Ross, S. R., \& Fisher, M. (2010). Academic clustering and major selection of intercollegiate student-athletes. College Student Journal, 44(1), 64-70.

Shurts, W. M. \& Shoffner, M. F. (2004). Providing career counseling for collegiate studentathletes: A learning theory approach. Journal of Career Development, 21(2), 95-109.

Sinclair, D., \& Orlick, T. (1993). Positive transitions from high-performance sport. The Sport Psychologist, 7(2), 138-150. 
Smith, A.B., \& Hardin, R. (2015, November). Former female student-athletes transition into athletic department graduate assistantships. North American Society for the Sociology of Sport Conference. Santa Fe, NM.

Smith, A. B., Taylor, E. A., Siegele, J., \& Hardin, R. (2015, April). Transitioning into the next stage of life: A case study analysis of former collegiate baseball players journey to life after professional sport. Collegiate Sport Research Institute. Columbia, SC.

Stankovich, C. E., Meeker, D. J., \& Henderson, J. L. (2001). The positive transitions model for sport retirement. Journal of College Counseling, 4(1), 81-84.

Sutherland, L.M., Kowlaski, K. C., Ferguson, L. J., Sabiston, C. M., Sedgwick, W. A., \& Crocker, P. R. E. (2014). Narratives of young women athletes' experiences of emotional pain and self-compassion. Qualitative Research in Sport, Exercise Science, and Health, $6(4), 499-514$.

Upton, J. \& Novak, K. (2008, November 18). College athletes cluster majors at most schools. USA Today.

Veal, A. J., \& Darcy, S. (2014). Research methods in sport studies and sport management. London: Routledge.

Werthner, P., \& Orlick, T. (1986). Retirement experiences of successful Olympic athletes. International Journal of Sport Psychology, 17, 337-363.

Yin, R. K. (1994). Case study research: Design and methods (2 ${ }^{\text {nd }}$ ed.). Newbury Park, CA: Sage Publications. 